\title{
Upfront
}

\section{Thank You, Wendy}

\author{
NICOLA BULLARD \\ AND THE \\ DEVELOPMENT \\ COMMUNITY
}

\begin{abstract}
Global voices assemble to celebrate Wendy Harcourt's 18 years of leadership of the Development journal.

KEYWORDS alternative perspectives; dialogue; feminism; gender and development; local perspectives; people centred development; sustainable development; sustainable livelihoods
\end{abstract}

After 18 years, Wendy Harcourt has stepped down as Editor of Development. As SID wrote in their press release announcing the news, 'Wendy has been quite simply a unique Editor'. Many of you will have enjoyed Wendy's editorials and appreciated the breadth and freshness of her intelligence. The enduring quality and prestige of the journal is testimony to her work, and the calibre and accomplishments of the new Editor - Tariq Banuri - speaks to the tradition that is being continued. However, more than anything, it is the words of friends and colleagues that give a measure of Wendy's qualities and contributions.

Reading through the dozens of tributes that arrived from across the world, there are two remarks in particular that struck a note with me. The first is Wolfgang Sach's observation (and admiration) of Wendy's 'timid and searching' character and how quickly her 'timidity turned into tenacity and her search into determination'. The second is Jacqueline Pitanguy's simple comment that, in addition to everything else - en plus, she says - Wendy is lovely to be with. How true that is.

Like others, I first met Wendy through SID. At the last minute, I was pulled off the bench to replace Walden Bello at the Santiago de Compostela Congress in 1997. Knowing no one and feeling out of my depth, someone kindly introduced me to Wendy as a fellow Australian. I remember that she was wearing a rather nice, if demure, mossgreen knitted dress. This is not irrelevant. Those who know Wendy also know that she has an eye for beauty: textures, colours, shimmering fabrics, delicate designs. The aesthetics she brings to her life are reflected in the aesthetics she brings to her work, both as an Editor and as an intellectual: an interest in and an eye for nuance, suggestion, detail, quality, elegance, eclecticism and the exotic.

But these reflections would come later, as I came to know Wendy. The paper I gave at the conference turned into an article for Development and that, in turn, grew into an association with SID. Hence our exchanges continued and our friendship grew. In the early 2000s, Wendy asked me to join the Editorial advisory board, proof of her openness to social movements, activists and system-critical thinking. In 2005, she invited me to write a guest editorial on 'The Movement of Movements' and, taking an even greater risk in 2008, allowed me to guest edit the issue 'The Future of Agriculture'. It was only then 


\section{Bullard: Thank You, Wendy}

that I fully understood the work of the editor: the relentless cascade of emails, deadlines, reminders, follow-up, selection, discussion, editing, proofing and checking that goes into creating a journal, to say nothing of the diplomacy, the intellectual work, the detailed reading, the capacity to engage at multiple levels with a wide range of people on dozens of different topics ... And to do this four times a year for 18 years? Frankly, she deserves a medal.

Sensibly, Wendy organized her work to make sure that she was engaged in interesting and diverse discussions with interesting and diverse people on the main issues of the day and, more importantly, those that should be the main issues of the day. Topics ranged far and wide, from agriculture to the digital world, from body politics to greening the economy, from violence to institutions. But no matter how far the authors wandered or the issues proliferated and fragmented, Wendy - who is both a skilled shepherd and intellectually relentless managed to bring it all together in ways that made sense, challenged orthodoxies, opened our ears to new voices and - not unimportantly - ensured that the authors felt respected and heard.

Above all, Wendy was generous in sharing the public space created by the journal: she sought out and encouraged contributions from thinkers and doers, activists and academics. As Arturo Escobar says, she created hybrid and inclusive spaces where we could value and explore diversity, and where real conversations were happening. What's more, Wendy has the capacity to make each author feel that her or his contribution was crucial and valued, a capacity no less sincere for being one of the guiles of any great Editor.

As an Australian woman, living in Italy, as a feminist, a mother, a daughter and a spouse, and as an intellectual, an activist and an expatriate, Wendy takes identity and place seriously. Because of this, she is very open. She shares these tensions, histories, contradictions and experiences in her encounters with others and is elegantly unpretentious. We have all seen how she facilitates meetings, bringing people together with calmness and intent.

Many of Wendy's qualities - intelligence and determination, a quiet charisma and a huge capacity for hard work - were expressed in her editorial work. This is why Development is so well respected and why Wendy will be so missed in her role as Editor. But she is alive and thriving, at the Institute of Social Studies in the Hague she will continue to be our friend and colleague, and she will undoubtedly continue to evolve, to grow, to create and to produce.

There is much more to say, but I am sure there will be other chances to acknowledge and celebrate Wendy's two decades of work with SID and Development, and of course to wish her all the best for the future. In the meantime, I give the page to other friends and colleagues.

\section{Ana Agostino}

Thanks to Wendy for her remarkable capacity to put together an excellent journal during 20 years with the same enthusiasm of the very first issue, while making every contributor feel how crucial his or her article was for deepening the debate around development from a myriad of perspectives. I consulted Development on a regular basis while writing my $\mathrm{PhD}$ at UNISA, and was elated when invited to join the Editorial Board. Since then, I have not ceased to be surprised by Wendy's working capacity, her rigour, her ability to bring together authors from various backgrounds, to generate debate, to motivate.

\section{Fatma Alloo}

At first I was shocked at the news, although it was not so sudden and I kind of knew, but the mind takes time to accept what has been so comfortable for us: Wendy's inputs into the journal and how she spent energy to mobilize us and keep us involved. The wonderful meetings, the rapport, the fun, the tears and how we were there for each other. I first met Wendy in the NorthSouth dialogue organized by ABANTU in Rome and our first encounter (oh, we were ever so young!!!!) was stormy to say the least but, being as she is, we ended up publishing an article together on the North-South issues in Gender and Development.

Seeing all the names of those giving tribute to Wendy gives me a warm feeling of the community 
we have built. To all of you those who know and those who do not, just to say to you that for the last six months, I have battled cancer and now have bounced back. In fact, I have just finished coordinating and teaching social movement class to 31 undergraduates who are on studies abroad programme for seven weeks in Tanzania from 25 US universities and the programme is Beyond Globalization! Development has been one of the major resources at their disposal in the library I set up and they have utilized it for the last eleven years that I have been coordinating this programme. So Wendy, there you go.

\section{Lydia Alpízar}

Although Wendy has been the Editor of the SID journal for nearly 20 years, she has always been so much more than an Editor in the collaborations between AWID and SID. She has been an incredibly active and thoughtful feminist activist and provocateur, she has challenged our thinking and cheered us on in difficult times, she has raised critical questions and facilitated connections between people and themes, and suddenly, there is a fabulous written product, a well-regarded journal that somehow brings all the pieces together. Wendy's collaboration has been invaluable in helping AWID to capture some of the feel and insights from our triennial Forums on women's rights and development. We will miss her in this role but have no doubt that our close collaborations will continue. Many thanks to you Wendy, we wish you all the very best!

\section{Franck Amalric}

It is quite amazing how massive the changes have been on the world scene during the time Wendy has edited Development: The end of the Cold War; the emergence of environmental concerns on the global scene; a global civil society; economic globalization. During that time, Wendy made Development a place where the hopes, visions and struggles of civil society and social movements South and North were presented and discussed in relation to these changes and emerging chal- and mainstream development thinkers and doers could tentatively take place.

The journal thus carried a great ambition: to transcend the divide between groups with different political agendas; to transcend disciplinary boundaries; to bridge the local to the national and to the global following the idea of a 'politics of place' that Wendy later conceptualized. Wendy carried this ambition forward, pulling in social movement leaders, engaged and non-engaged academics, Nobel prize winners, heads of UN agencies, all with ridiculously few resources and relying entirely on her energy and capacity to draw in a wide diversity of persons. I have always been amazed how swiftly Wendy was able to bring out new issues of Development quarter after quarter.

\section{Marisa Belausteguigoitia Rius}

I have many things to thank Wendy, ranging from academic to affective, from conceptual to material. Her vision on crossing borders regarding forms of dispossession, empowerment, transformation of women transnationally, has left evidence through her work as creative Editor of Development, in her inspired writing and through her engineering of so many different transnational projects. Through her I have met the most wonderful people, the most exciting topics and places; her involvement with tensions regarding precarity, oppression, and woman's forms of resistance has produced strategic knowledge to understand the mechanics of inequality, but also, joy, friendship, solidarity and deep transformation. We began to work together through Women in the Net in 1994. Today, we find an enormous assemblage of interrelated academics, friends, activists, journalists, writers, artists, entrepreneurs that have been touched by the spiral strings of her thinking, her acting and her weaving of emotions, ideas, working groups and new ways of understanding change and affection.

\section{Arturo Escobar}

Wendy's leadership has been both intellectual steering the journal through the complex debates of the past decade - and organizational, in terms of effective fund raising, diverse type of meetings, 


\section{Bullard: Thank You, Wendy}

and the creation of hybrid spaces for debate that brought together Development's main constituencies (academics, activists, policy and NGO people, students, etc.). Wendy managed to do all of this brilliantly and effectively, introducing new topics and perspectives that other journals have skewed or only treated lightly. I am thankful for having had the opportunity to be part of the journal under Wendy's leadership, and of the amazing group of people she brought together in the editorial groups.

\section{Jessica Horn}

I first encountered Wendy Harcourt through Arturo Escobar. I was a student at Smith College and had taken one of Professor Escobar's classes on the Anthropology of Development at UMASS Amherst - yearning as I was for post-colonial and feminist perspectives and critique on our collective history. In Wendy's work, I also found an echo of another passion - the place and agency of the body. Wendy Harcourt has been a critical voice insisting on bringing the body front and centre into our understandings of development, society and social change. She has also been insistent on the need to embrace the plurality of embodied perspectives on the world, and active in sustaining platforms to profile the activism and analysis of women from across the global South including in her leadership as Editor of Development. Thank you Wendy!

\section{Enrique Iglesias}

I'm really very sad to see Wendy leaving Development Journal. It's impossible to improve on the sentiments of others that I fully share. She has made an immense contribution, with her inspiration, creativity and her superb selection.

\section{Richard Jolly}

Wendy has done great work for many years to maintain the liveliness and professional quality of SID's Development Journal. She has provided truly exceptional and highly professional service and creative leadership as Editor.

\section{John Langmore}

Wendy has made an outstanding contribution to global development, especially through her emphasis on gender equity in human development. She has fulfilled the Editorship of Development with efficiency, effectiveness and imagination. To have maintained such strength of commitment for 25 years, 17 of them as Editor is a remarkable achievement. Her intellectual, political and moral challenges to readers have been an inspiration. Wholehearted best wishes to her for continuing scholarly and authorial vitality - and perhaps some occasional leisure.

\section{Stephen F. Moseley}

Wendy's leadership in the composition, direction and substance of the SID Development Journal has enabled all of us in the international development community to learn, study, debate and respect the enormous range of valuable perspectives on the challenges and potential solutions to the needs of people disadvantaged by poverty and discrimination. She has shaped a full generation of development policy leaders and implementers to better understand the need for open minds, and to embrace alternative perspectives about economic change, gender equality and empowerment, human rights and the respect for local voices. The body of her work and editorials in the Development Journal, including her distinct mark by the careful choice and nurturing of the writers over 20 years, is a legacy for her and for SID's place in development history. These are references that will retain their value over time, and deserve our support to be sustained and made available to the coming generations of young active change leaders in societies around the world.

Wendy has never failed to encourage, engage and challenge us to put forth our best as contributors and advisors to the journal, but not for a moment would our participation have been valuable without her leadership to define, position and juxtapose our thoughts with a purpose and framework she so thoughtfully and beautifully created for each volume and edition year after year. Fortunately, we can now all benefit by asking 
her to continue to contribute her own thoughts and views through her own writing for the journal under the able new Editorship of Tariq Banuri.

\section{Helen O'Connell}

I first met Wendy at one of the early meetings of WIDE (Network Women and Development Europe) in Oxford around 1986 or 1987. WIDE at the time was struggling to become established after its first exciting meeting in late 1985 in Amsterdam. To everyone's delight and amazement, Wendy volunteered to edit the WIDE Bulletin, a role she played enthusiastically for many years. Since that time, Wendy and I have become close friends and have worked together within WIDE, on the Editorial board of Development and in numerous international gatherings.

Wendy's contribution to the Journal Development has been enormous. Her clear feminist vision, deep knowledge and sharp analysis, her immense network of international contacts, and her quiet efficiency have made Development what it is today, a highly relevant, timely and thorough investigation of current debates and issues. Working with Wendy as a member of the Editorial board has been a privilege and a pleasure.

Wendy's contribution to women's rights, gender equity and international issues goes well beyond the journal. Her feminist research and writing in her many books, articles and lectures are eagerly read and highly influential.

I look forward to many more years of close working relations and friendship.

\section{Jacqueline Pitanguy}

I met Wendy in times of hope and political activism, when the international conferences of the 1990s opened the UN doors to new political actors, and when declarations and plans of action framed under the human rights principles advanced women's struggles against violence, for reproductive rights, for full equality. These were great times to meet someone like Wendy: because she is deeply committed to gender equality, an activist and an intellectual with whom I immedi- someone you can trust, with whom you share a cause, someone you would like to work with, and because she is lovely to be with. I am lucky to have been close to Wendy since then, in different research projects, during my many years with the SID Governing Board, and with the Development Editorial board. The qualities I have sensed when I first met Wendy remained and grew throughout these many years. Congratulations Wendy on your professional excellence, on your integrity, on you commitment to the never-ending cause of women's rights. And thank you for remaining such a delightful person to be with.

\section{Stefano Prato}

It is not easy to find the words to celebrate Wendy's achievements. I feel that any attempt would end up in an understatement. As many of you are aware, the circumstances of SID's operations have often been challenging over the past years. Despite the many transitions and critical junctures, Wendy always ensured the quality production of Development. Not only has the journal continued to be the flagship of our Society, it has often been that moment of clear light during dark times. I am grateful to Wendy for her untiring and restless attitude, intellectual guidance and charming capacity to engage us all whenever the journal required. But for every extra mile each of us might have walked, she walked hundreds! For these and millions of other reasons, I believe it is important for the Society to celebrate Wendy's impressive achievements. I am fully committed to finding ways for this, and hope that I can count on your ideas and support.

\section{Shobha Raghuram}

Development Journal achieved a great deal because somehow Wendy managed to not lose sight of the whole ... in a world of increasing fragmentations and posturing sound bytes replacing serious scholarship she succeeded in bringing together writers, activists, bureaucrats and donors who believed in the need for equity and social justice. For Wendy, it was not just another article but the 


\section{Bullard: Thank You, Wendy}

history of the person writing that also mattered. In this sense Development managed to break the distances that prevent scholars from walking the path of serious social change with activists and practitioners. As Editor, she did not set aside the dissenting voice but remained democratic without losing sight of the issues the journal was trying to confront.

I cannot forget when we met in the Hague when Smitu joined us for the last time ... much has happened during the years spent together and it has meant a lot to me personally and professionally that we as a collective stood by each other through the times, difficult as they have been.

\section{Sadig Rasheed}

Without Wendy's dedication, commitment and talent, the journal would not have achieved the status it now has. Wendy will be sorely missed, but she deserves to have the career that she always wanted. I delightfully join all my colleagues in offering sincere thanks to Wendy for her commitment and leadership, and also wish her the very best wishes in the years ahead.

\section{Wolfgang Sachs}

It was more or less in 1990 that I met Wendy, the outgoing Editor, in Rome and the incoming Editor, Tariq, at Harvard Square for the first time, he eloquent and inspiring, she timid and searching. I was admiring how quickly Wendy's timidity turned into tenacity and her search into determination. She has had the courage to open the journal - not an easy task in an SID environment to unconventional thinkers, to the grassroots in the field, last but not least to many feminist voices. Congratulations to Wendy and Tariq.

\section{Roberto Savio}

Even if I have been confined to an invisible role since leaving my post of Secretary General, I have been following Development with great interest. Wendy was able to make of the journal a very large tent, in which so many interrelated but usually separated subjects were treated.

\section{Upananda Vidanapathirana}

SID Sri Lanka Chapter wishes to place on record it's appreciation to the intellectual contribution made by Wendy as Journal Editor. She was a sincere friend who inspired all of us. She was a source of strength for us when we faced the challenge of hosting the 50th Anniversary Conference of SID South Asia in Colombo.

\section{Gillian Youngs}

Well, the end of a landmark era for Development and the beginning of another not only for Wendy in her 'brilliant career' but also in the life of the journal. There is far too much to say about the excellence, dynamism and real world import that her work has brought to the journal over the years of amazing and inspiring leadership. Development has broken so many boundaries in redefining what a serious scholarly and in depth policy-relevant publication should be. I have been very happy to be associated with it and the distinctive approach it takes in bringing quality research and applied insights to such a wide and diverse public. Among its many qualities has been the breadth of the voices it has involved and engaged. It stands out on the international scene. Bravo Wendy on steering the work so inclusively and with such commitment over the years. 